\title{
Zagadnienia wydawnicze w nauce o ksiąice
}

STRESZCZENiE: Przedmiotem artykułu jest obecność problematyki zagadnień wydawniczych w publikacjach teoretycznych z zakresu bibliologii. Głównym celem opracowania jest przedstawienie różnych sposobów postrzegania problematyki zagadnień wydawniczych przez teoretyków nauki o książce. Zastosowano metodę analizy i krytyki piśmiennictwa, poddając analizie polskie prace z zakresu teorii i metodologii nauki o książce, wydane w latach 1975-2010. Przeprowadzono analizę głównych kierunków refleksji teoretycznej i metodologicznej w nauce o książce, ustalono podstawowe kierunki badań nad zagadnieniami wydawniczymi na gruncie bibliologii oraz sformułowano wnioski dotyczące miejsca zagadnień wydawniczych w obszarze badawczym nauki o książce.

SŁOWA KLUCzowe: analiza i krytyka piśmiennictwa, kierunki badań w nauce o książce, teoria i metodologia nauki o książce, zagadnienia wydawnicze w bibliologii

\section{Wprowadzenie}

Dozważania dotyczące miejsca zagadnień wydawniczych w polu baNań bibliologii były wielokrotnie uwzględniane przy omawianiu metodologicznych założeń nauki o książce. Związki bibliologii z problematyką zagadnień wydawniczych podkreślił między innymi Stanisław Kondek, pisząc: „Wielu dziewiętnastowiecznych historyków, bibliogra- 
fów i bibliotekoznawców podejmowało badania nad drukarniami, papiernictwem, introligatorstwem, oficynami wydawniczymi, ich repertuarem, nakładami i postacią materialną wydawanych publikacji. Badania te, prowadzone bez ściśle określonej metodologii i o różnie zakreślonych celach, przyniosły wiele ważnych ustaleń faktograficznych, ale nie tworzyły usystematyzowanej całości, nie pozwalały na szersze uogólnienia"1 Dopiero wykrystalizowanie się bibliologii jako dyscypliny naukowej pozwoliło - zdaniem S. Kondka - usystematyzować badania nad zagadnieniami wydawniczymi.

Encyklopedia wiedzy o książce (dalej: EWoK), publikacja obejmująca zgodnie z deklaracjami autorów - „całokształt [...] wiedzy ze wszystkich dziedzin dotyczących książki jako dzieła sztuki rękopiśmiennej i poligraficznej oraz przedmiotu czytelnictwa, kolekcjonerstwa i handlu"2, wymienia zagadnienia wydawnicze jako jedną z omawianych dziedzin. Zagadnienia wydawnicze są w indeksie rzeczowym ostatnią, XVI kategorią tematyczną ${ }^{3}$ EWoK nie definiuje jednak samego pojęcia.

Encyklopedia współczesnego bibliotekarstwa polskiego (dalej: EWBP) zalicza zagadnienia wydawnicze do pierwszego z szesnastu przyjętych zakresów tematycznych, wymieniając edytorstwo i ruch wydawniczy w dziale Zagadnienia ogólne. Teoria, w części drugiej Nauki i dziedziny pomocnicze. Podobnie jak EWoK, również EWBP nie przytacza definicji terminu zagadnienia wydawnicze ${ }^{4}$.

$\mathrm{Na}$ trudności w zdefiniowaniu zakresu znaczeniowego terminu zagadnienia wydawnicze zwraca uwagę Leon Marszałek, podkreślając, że: „samo określenie zagadnienia wydawnicze nie jest jednoznacznie rozumiane w praktyce, jak również w nauce o książce"5. Zdaniem autora trudność w zdefiniowaniu zakresu pojęciowego zagadnień wydawniczych opiera się na dwóch podstawowych wątpliwościach: co jest „przedmiotem wydawania” oraz jakie czynności mogą być określone mianem „wy-

S. Kondek, Zagadnienia wydawnicze i księgarskie, Warszawa 2010, s. 17.

2 Encyklopedia wiedzy o książce, pod red. A. Birkenmajera, B. Kocowskiego, J. Trzynadlowskiego, Wrocław-Warszawa-Kraków 1971.

3 Tamże, sz. 2742-2753.

${ }^{4}$ Encyklopedia współczesnego bibliotekarstwa polskiego, kom. red. K. Głombiowski, B. Świderski, H. Więckowska, Wrocław 1976.

${ }^{5}$ L. Marszałek, Zagadnienia wydawnicze w nauce o książce, [w:] Metodologia bibliotekoznawstwa i nauki o informacji naukowej, pod red. S. Kubiaka, Poznań 1976, s. 47. 
dawniczych"6. Podobne wypowiedzi pojawiły się w publikacjach Jana Trzynadlowskiego ${ }^{7}$ i Marka Tobery ${ }^{8}$.

Na potrzeby artykułu zagadnienia wydawnicze zostaną zdefiniowane jako ogół kwestii związanych z organizacją procesu wytwarzania książek i wprowadzania ich do obrotu. Do zagadnień wydawniczych nie zostanie w takim ujęciu zaliczona działalność księgarska ani też działalność wydawnicza w odniesieniu do czasopism.

\section{Cel i przedmiot badania}

Zdaniem L. Marszałka „zagadnienia wydawnicze w szerszym lub węższym ujęciu były zawsze uwzględnione przy omawianiu metodologicznych założeń nauki o książce" ${ }^{\prime \prime}$. W nawiązaniu do tezy L. Marszałka przedmiot tego badania stanowi obecność problematyki zagadnień wydawniczych w publikacjach teoretycznych z zakresu bibliologii. Głównym celem niniejszego opracowania jest przedstawienie wybranych kontekstów postrzegania problematyki zagadnień wydawniczych przez teoretyków nauki o książce.

Wśród szczegółowych celów podjętych badań można wymienić:

- analizę głównych kierunków refleksji teoretycznej i metodologicznej w nauce o książce,

- analizę wybranych koncepcji dotyczących miejsca zagadnień wydawniczych w obszarze badawczym bibliologii,

- ustalenie głównych kierunków badań nad zagadnieniami wydawniczymi na gruncie nauki o książce.

\section{Metoda}

W celu rozpoznania głównych kierunków badań nad zagadnieniami wydawniczymi na gruncie nauki o książce posłużono się metodą analizy i krytyki piśmiennictwa. Analizie poddano polskie prace z zakresu teorii

6 Tamże.

7 J. Trzynadlowski, Edytorstwo i zagadnienia wydawnicze. Stan i perspektywy badawcze, „Studia o Książce” t. 12: 1982, s. 59-66.

8 M. Tobera, Bibliologia wobec polskiego rynku książki w latach 1944-2007, „Przegląd Biblioteczny" R. 76: 2008, z. 1, s. 39-66.

9 L. Marszałek, dz. cyt., s. 48. 
i metodologii nauki o książce, wydane w latach 1975-2010. Wyboru publikacji do analizy dokonano, posługując się „Polską Bibliografią Bibliologiczną"10. Podstawowym kryterium doboru publikacji była ich zgodność z przyjętym przedziałem czasowym oraz zakres tematyczny odpowiadający celom pracy.

Pod uwagę zostały wzięte:

- ze względu na formę: monografie, prace zbiorowe, artykuły z czasopism naukowych;

- ze względu na treść: opracowania teoretyczne i metodologiczne o charakterze ogólnym z dziedziny bibliologii (w tym opracowania teoretyczne i metodologiczne związane bezpośrednio z zagadnieniami wydawniczymi);

- ze względu na zasięg chronologiczny: publikacje z lat 1975-2010.

Wykluczone zostały:

- ze względu na formę: sprawozdania z konferencji, raporty itp.;

- ze względu na treść:

- opracowania teoretyczne i metodologiczne z dziedziny informacji naukowej,

- opracowania teoretyczne i metodologiczne z dziedziny bibliotekoznawstwa,

- opracowania teoretyczne i metodologiczne o charakterze szczegółowym (np. poświęcone omówieniu konkretnej metody, poszczególnych rodzajów źródeł do badań itp.),

- prace poświęcone problematyce wydawniczej, ale niemające charakteru metodologicznego (np. ruch wydawniczy na danym obszarze lub w danym przedziale czasowym).

Przyjęte założenia doprowadziły do ograniczenia liczby analizowanych publikacji, pozwoliły lepiej skupić się na celach pracy, a więc poszukiwaniu w literaturze teoretycznej i metodologicznej z dziedziny bibliologii śladów te o r e ty c z n e j r efle ks j i na temat miejsca zagadnień wydawniczych w polu ba dán nauki o książce.

Analizie poddano ogółem 5 monografii, 5 artykułów opublikowanych w pracach zbiorowych oraz 16 artykułów z czasopism naukowych.

10 „Polska Bibliografia Bibliologiczna” za lata 1975-2010. 
Stan badań

Bezpośrednią inspiracją do powstania niniejszego tekstu był artykuł Zagadnienia wydawnicze $w$ nauce o ksiq̨żce autorstwa L. Marszałka, opublikowany w 1976 r. w materiałach z konferencji Metodologia bibliotekoznawstwa i nauki o informacji naukowej ${ }^{11}$. Artykuł Marszałka poświęcony został problematyce obecności zagadnień wydawniczych w polu badań nauki o książce, począwszy od XIX w., aż do roku 1975. W niniejszym tekście podjęto próbę kontynuacji pracy Marszałka - stąd przyjęty zasięg chronologiczny 1975-2010.

Marszałek poddał analizie prace wybranych teoretyków nauki o książce, śledząc ewolucję sposobów postrzegania problematyki zagadnień wydawniczych oraz analizując przyczyny zachodzących zmian. Przeprowadzona analiza skłoniła autora do stwierdzenia, że „zmiany zachodzące w ruchu wydawniczym [...] decydują o coraz intensywniejszej potrzebie rozwijania badań w zakresie wiedzy wydawniczej"12. Zdaniem Marszałka „koncepcja odrębnej dyscypliny w obrębie nauki o książce zajmującej się zagadnieniami wydawniczymi stała się niemal koniecznością"13.

Analiza prac takich autorów, jak Kazimierz Dobrowolski, Karol Głombiowski, Adam Łysakowski, Jan Muszkowski, Kazimierz Piekarski czy Mieczysław Rulikowski, skłoniła Marszałka do stwierdzenia, że „polscy teoretycy nauki o książce w swych opracowaniach metodologicznych prawie z reguły poświęcają uwagę zagadnieniom wydawniczym" ${ }^{\prime 14}$. Autor podkreślał przy tym jednak, iż prowadzone badania nie mają w większości systematycznego charakteru. Postulował zatem uprawianie badań nad zagadnieniami wydawniczymi w ramach oddzielnej dyscypliny, zaznaczając, że „dyscyplina ta powinna znaleźć miejsce w nauce o książce"15.

Kolejną pracą, interesującą z punktu widzenia celów analizy, jest artykuł J. Trzynadlowskiego Edytorstwo i zagadnienia wydawnicze. Stan i perspektywy badawcze $e^{16}$, omawiający przedmiot badań edytorstwa oraz kierunki polskich badań nad zagadnieniami wydawniczymi. Niezwykle użyteczny, szczególnie w zakresie ustaleń terminologicznych, okazał

11 L. Marszałek, dz. cyt.

12 Tamże, s. 53.

13 Tamże, s. 54

14 Tamże, s. 50

15 Tamże, s. 56.

16 J. Trzynadlowski, dz. cyt. 
się również artykuł M. Tobery Bibliologia wobec polskiego rynku książki w latach $1944-2007^{17}$ oraz praca Bożeny Koredczuk Kształtowanie się definicji i zakresu bibliologii w polskich encyklopediach i słownikach XIX i XX wieku ${ }^{18}$.

\section{Teoria i metodologia nauki o ksiq̨żce: główne kierunki rozważań}

Analiza częstotliwości publikowania wytypowanych prac o charakterze teoretycznym i metodologicznym z dziedziny bibliologii wykazała, że najwięcej publikacji z omawianego zakresu tematycznego ukazało się w latach 1981-1985, najmniej zaś w latach 1996-2000 (wykres 1).

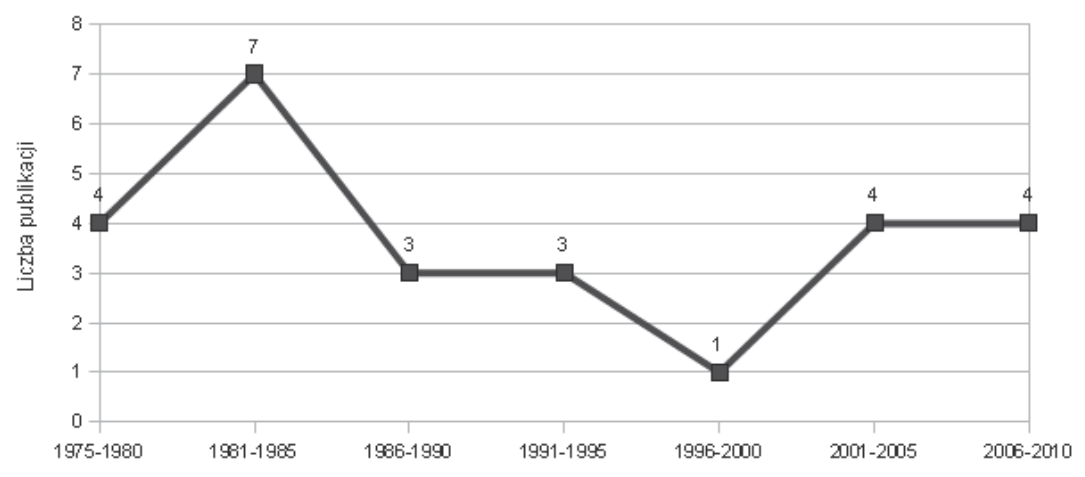

Wykres 1. Częstotliwość publikowania prac o charakterze teoretycznym i metodologicznym z dziedziny bibliologii w latach 1975-2010

Źródło: opracowanie własne.

Począwszy od roku 2000, liczba analizowanych publikacji systematycznie rosła, uzyskując w latach 2006-2010 poziom taki jak w latach 1975-1980. Trzeba jednak podkreślić, że analizowane publikacje n i e reprezentują całości wydawnictw teoretycznych i metodologicznych z dziedziny bibliologii wydanych w latach 1975-2010, a jedynie sygnalizują tendencje w zakresie częstości pojawiania się specyficznej gru-

17 M. Tobera, dz. cyt.

18 B. Koredczuk, Kształtowanie się definicji i zakresu bibliologii w polskich encyklopediach i słownikach XIX i XX wieku, [w:] Oblicza kultury książki. Prace i studia z bibliologii i informacji naukowej, pod red. M. Komzy, Wrocław 2005, s. 53-75. 
py prac związanych z analizą przedmiotu badań nauki o książce oraz jej pola badań.

Zakres tematyczny analizowanych publikacji mieścił się w obrębie ośmiu głównych kategorii:

I. Stan i kierunki badań bibliologicznych,

II. Przedmiot badań nauki o książce,

III. Rozważania terminologiczne,

IV. Wzajemne relacje bibliologii, bibliotekoznawstwa i informacji naukowej,

V. Teoria bibliologii a kształcenie w zakresie bibliotekoznawstwa,

VI. Metodologia (prace ogólne),

VII. Perspektywy rozwoju dyscypliny, postulaty dalszych badań,

VIII. Związki teorii i ,praktyki w badaniach bibliologicznych.

Najliczniej reprezentowane były prace omawiające przedmiot i zakres badań nauki o książce (63\%). Na kolejnych miejscach znalazły się publikacje prezentujące stan i kierunki badań bibliologicznych (31\%), rozważania terminologiczne $(18 \%)$ oraz prace związane z problematyką wzajemnych relacji bibliologii, bibliotekoznawstwa i informacji naukowej (18\%). Nieco rzadziej pojawiały się ogólne prace metodologiczne (14\%) oraz publikacje omawiające związki teorii i praktyki w badaniach bibliologicznych (14\%). Najmniej licznie były reprezentowane prace przewidujące perspektywy rozwoju dyscypliny lub zawierające postulaty dalszych badań (9\%) oraz teksty poświęcone wpływowi teoretycznych ustaleń nauki o książce na proces kształcenia w zakresie informacji naukowej i bibliotekoznawstwa (4,5\%).

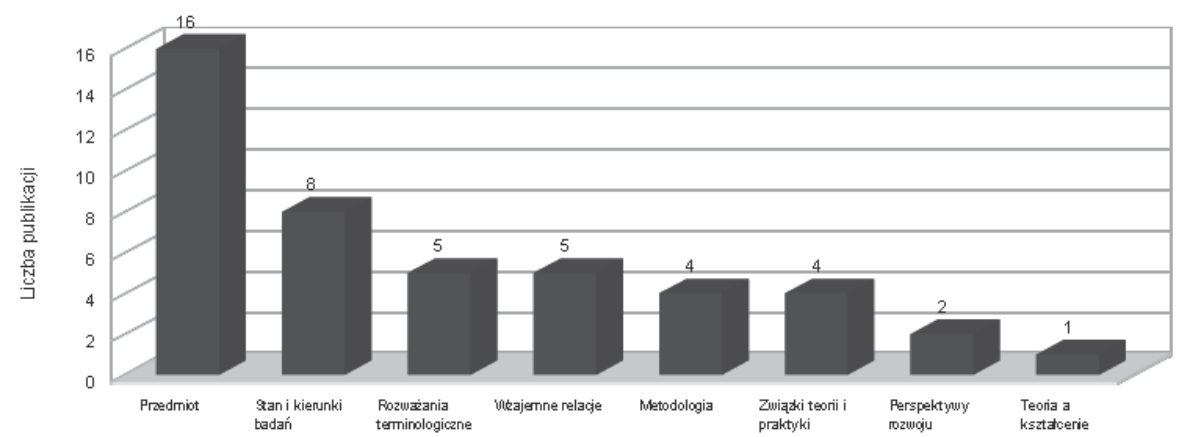

Wykres 2. Częstość publikowania prac w ramach przyjętych zakresów tematycznych (ranking)

Źródło: opracowanie własne. 


\section{Zagadnienia wydawnicze w nauce o ksiąice}

Ślady teoretycznej refleksji na temat miejsca zagadnień wydawniczych w polu zainteresowań nauki o książce można odnaleźć w niemal połowie analizowanych publikacji (48\%).

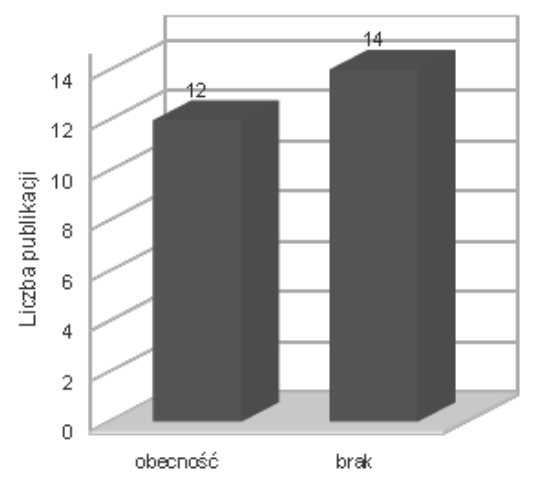

Wykres 3. Obecność problematyki zagadnień wydawniczych w analizowanych publikacjach

Źródło: opracowanie własne.

Sposoby ujęcia tematu zagadnień wydawniczych można przy tym przyporządkować do jednej z trzech ogólnych kategorii.

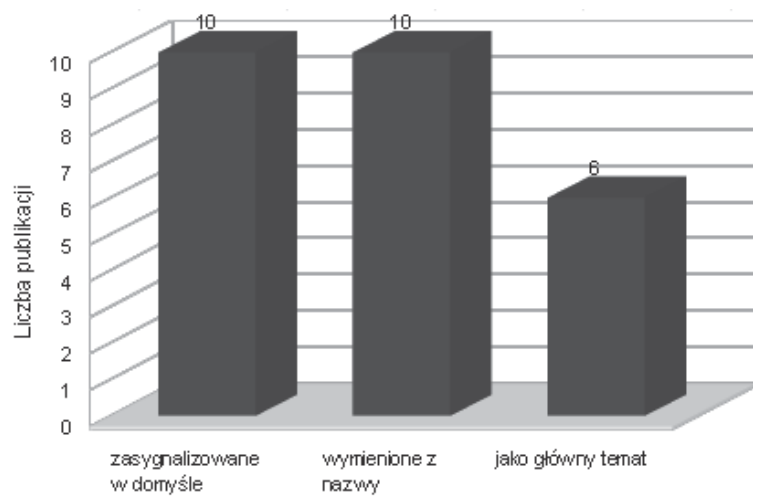

Wykres 4. Sposób ujęcia tematu zagadnień wydawniczych w analizowanych publikacjach

Źródło: opracowanie własne. 
Pierwszą grupę tworzą prace, w których przedmiot nauki o książce został syntetycznie określony, na przykład jako:

- „całość piśmiennictwa oraz procesy bibliologiczne, na które składają się: produkcja książek [...], obieg ich w społeczeństwie [...] oraz konsumpcja, a więc czytelnictwo"19;

- „książka i procesy bibliologiczne: tworzenie, obieg, konsumpcja książki, a także skutki tych procesów oraz ludzie i instytucje w nich uczestniczące" ${ }^{20}$;

- „splot zagadnień dotyczących teorii, historii i współczesności książki, bibliotek, informacji, ich tworzenia, rozpowszechniania, odbioru i funkcji"21;

- „książka jako jednolity organizm i potencjał kulturalny, procesy bibliologiczne, ludzie i instytucje książki"22;

- „rodzaj komunikacji międzyludzkiej, w którym jako ogniwo główne występuje książka"23;

- „kultura książki”"24.

Zagadnienia wydawnicze nie zostały więc wymienione wprost jako przedmiot zainteresowania nauki o książce, można jednak zakładać, że mieszczą się one w nakreślonym polu badań.

Drugą - najciekawszą z punktu widzenia celów artykułu - grupę publikacji tworzą prace, w których zagadnienia wydawnicze zostały wymienione wprost jako jeden z elementów obszaru zainteresowań nauki o książce. Takie ujęcie pojawiało się m.in. w pracach Jana Pomorskiego ${ }^{25}$, Zofii Gacy-Dąbrowskiej ${ }^{26}$ czy Radosława Cybulskiego ${ }^{27}$.

19 B. Sordylowa, Wzajemne relacje między dyscyplinami: informacja naukowa, bibliologia i bibliotekoznawstwo, „Przegląd Biblioteczny” R. 57: 1998, z. 4, s. 311.

${ }^{20}$ K. Migoń, Nauka o książce wśród innych nauk społecznych, Wrocław 1976, s. 48.

21 Tenże, O nazwie dyscypliny, którą uprawiamy, „Przegląd Biblioteczny” R. 61: 1993, z. $1 / 2$, s. 111

22 Tenże, Główne kierunki i perspektywy teorii księgoznawstwa, „Studia o Książce” t. $12: 1982$, s. 7-8.

${ }^{23}$ K. Głombiowski, Książka w procesie komunikacji społecznej, Wrocław 1980, s. 11.

${ }^{24}$ K. Migoń, Bibliologia - nauka o kulturze ksiq̨żki, „Nauka” 2005, nr 2, s. 49-57.

25 J. Pomorski, $W$ kierunku teoretycznej integracji badań bibliologicznych, „Studia o Książce" t. 15: 1985, s. 157-174.

26 Z. Gaca-Dąbrowska, Stan badań, potrzeby i perspektywy w zakresie bibliologii polskiej, „Przegląd Biblioteczny” R. 56: 1988, z. 3/4, s. 492-503.

27 R. Cybulski, Nauka o książce a doskonalenie systemu książki, „Studia o Książce” t. 18: 1989, s. 3-22. 
Jan Pomorski postrzega na przykład zagadnienia wydawnicze jako jedną z wyspecjalizowanych i uprawianych "niemal autonomicznie" ${ }^{28}$ gałęzi wiedzy, składających się na konglomerat dyscyplin tworzących bibliologię 29 . Zwraca przy tym uwagę na charakterystyczne dla przedstawicieli poszczególnych gałęzi tworzących naukę o książce poczucie posiadania wspólnego przedmiotu i celu badań oraz dążenie do „całościowej koncepcji przedmiotu poznania nauki o książce"30.

Zofia Gaca-Dąbrowska, dokonując przeglądu kierunków badań polskiej bibliologii, ujmuje z kolei edytorstwo i zagadnienia wydawnicze jako jedno z „ogniw życia książki”31. Autorka zauważa przy tym, że problematyka zagadnień wydawniczych na gruncie badań bibliologicznych mieści się w nurcie refleksji związanych z historią książki (głównie badań nad książką XIX i XX w.).

Radosław Cybulski postrzega zagadnienia wydawnicze jako element systemu książki oraz jedno z ogniw procesu komunikacji społecznej ${ }^{32}$, podkreśla przy tym złożoność społecznego procesu komunikacji, sugerując, że pełne poznanie zjawisk w obrębie tak nakreślonego pola badań jest możliwe dzięki ukształtowaniu się dyscyplin - w różnym stopniu autonomicznych - badających poszczególne jego ogniwa ${ }^{33}$.

Do grupy trzeciej zostały zaliczone cytowane już prace J. Trzynadlowskiego $^{34}$, L. Marszałka ${ }^{35}$ i M. Tobery ${ }^{36}$, w których teoretyczna refleksja nad wzajemnymi relacjami zagadnień wydawniczych i bibliologii stanowiła główny lub jeden z kluczowych elementów pracy. Warto zaznaczyć, że jest to najmniej liczna grupa publikacji.

Przytoczone przykłady pokazują, że problematyka zagadnień wydawniczych funkcjonuje w polu zainteresowań nauki o książce, jednak sposoby ujęcia tematu są różne. L. Marszałek stwierdził w 1976 r., że „obserwujemy postępujący proces interesowania się tymi zagadnieniami, a jednocześnie niejednolitość i wyraźnie dyskusyjny charakter ich ujęcia”. Konkluzja Marszałka wydaje się wciąż aktualna. Przeprowadzona analiza

\footnotetext{
28 J. Pomorski, dz. cyt., s. 158.

29 Tamże.

30 Tamże.

31 Z. Gaca-Dąbrowska, dz. cyt.

32 R. Cybulski, dz. cyt.

33 Tamże, s. 4.

${ }^{34} \mathrm{~J}$. Trzynadlowski, dz. cyt.

35 L. Marszałek, dz. cyt.

${ }^{36}$ M. Tobera, dz. cyt.
} 
dowodzi, że sposób postrzegania problematyki zagadnień wydawniczych na gruncie nauki o książce wciąż oscyluje od akceptacji aspektów wydawniczych jako jednego z tematów badawczych bibliologii, aż do uznania badań nad procesem wydawniczym za autonomiczną dyscyplinę.

\section{Podsumowanie}

Przeprowadzona analiza pokazała, że w polskich pracach z zakresu teorii i metodologii nauki o książce dominowały w latach 1975-2010 rozważania nad przedmiotem i zakresem badań nauki o książce oraz jej stanem i kierunkami rozwoju. Największa liczba publikacji z omawianego zakresu tematycznego ukazała się w latach 1975-1980, najmniejsza zaś w latach 1996-2000.

W niemal połowie analizowanych tekstów można było przy tym odnaleźć ślady refleksji teoretycznej nad miejscem problematyki zagadnień wydawniczych w polu badań nauki o książce. Zagadnienia wydawnicze były w nich zarówno wymieniane wprost jako element pola badań bibliologii, jak i sugerowane przez umieszczenie ich w szerszym kontekście kultury książki, systemu książki czy też procesu komunikacji społecznej.

Przeprowadzona analiza pozwala stwierdzić, że na gruncie nauki o książce funkcjonują - podobnie jak w XIX i w pierwszej połowie XX w. różne ujęcia problematyki zagadnień wydawniczych jako przedmiotu badań bibliologii. Tendencja do holistycznego postrzegania przedmiotu badań bibliologii jako ogółu zjawisk związanych z funkcjonowaniem książki w społeczeństwie pozwala sądzić, że problematyka zagadnień wydawniczych będzie w coraz większym stopniu włączana w obszar jej zainteresowań.

\section{Wykaz prac poddanych analizie}

1. Bednarska-Ruszajowa K., $Z$ teorii i metodologii księgoznawstwa i dziedzin pokrewnych, „Studia o Książce” t. 15: 1985, s. 289-298.

2. Bednarska-Ruszajowa K., $Z$ teorii i metodologii księgoznawstwa i dziedzin pokrewnych, „Studia o Książce” t. 16: 1986, s. 341-358.

3. Bednarska-Ruszajowa K., Z teorii i metodologii księgoznawstwa i dziedzin pokrewnych, „Studia o Książce” t. 19: 1993, s. 189-197. 
4. Cybulski R., Nauka o książce a doskonalenie systemu książki, „Studia o Książce" t. 18: 1989, s. 3-22.

5. Fercz J., Niemczykowa A., Podstawy nauki o książce, bibliotece i informacji naukowej, Warszawa 1991.

6. Gaca-Dąbrowska Z., Stan badań, potrzeby i perspektywy w zakresie bibliologii polskiej, „Przegląd Biblioteczny” R. 56: 1988, z. 3/4, s. 492-503.

7. Głombiowski K., Ksiq̨żka w procesie komunikacji społecznej, Wrocław 1980.

8. Głombiowski K., Teoria i metodologia nauki o książce, Gdańsk 1985.

9. Kordeczuk B., Kształtowanie się definicji i zakresu bibliologii w polskich encyklopediach i słownikach XIX i XX wieku, [w:] Oblicza kultury książki. Prace i studia z bibliologii i informacji naukowej, pod red. M. Komzy, Wrocław 2005, s. 53-75.

10. Łuszpak A., Filozoficzne inspiracje poglądów bibliologicznych Adama Łysakowskiego, [w:] Oblicza kultury książki. Prace i studia z bibliologii i informacji naukowej, pod red. M. Komzy, Wrocław 2005, s. 77-96.

11. Marszałek L., Zagadnienia wydawnicze w nauce o książce, [w:] Metodologia bibliotekoznawstwa i nauki o informacji naukowej, pod red. S. Kubiaka, Poznań 1976, s. 47-63.

12. Migoń K., Bibliologia - nauka o kulturze książki, „Nauka” 2005, nr 2, s. 49-57.

13. Migoń K., Bibliologia wśród innych nauk, koncepcje, realizacje, perspektywy, [w:] Bibliologia: problemy badawcze nauk humanistycznych: praca zbiorowa, pod red. D. Kuźminy, Warszawa 2007, s. 13-24.

14. Migoń K., Główne kierunki i perspektywy teorii księgoznawstwa, „Studia o Książce" t. 12: 1982, s. 5-17.

15. Migoń K., Metodologia badań księgoznawczych, [w:] Metodologia bibliotekoznawstwa i nauki o informacji naukowej, pod red. S. Kubiaka, Poznań 1976, s. 65-73.

16. Migoń K., Nauka o ksiq̨żce wśród innych nauk społecznych, Wrocław 1976.

17. Migoń K., Nauka o ksiq̨żce. Zarys problematyki, Wrocław 1984.

18. Migoń K., O nazwie dyscypliny, którq uprawiamy, „Przegląd Biblioteczny” R. 61: 1993, z. 1/2, s. 109-113.

19. Migoń K., O przedmiocie badań współczesnej bibliologii. Konspekt [on-line] 2004, nr 19 [dostęp 30 listopada 2011]. Dostępny w World Wide Web: http://www.up.krakow.pl/konspekt/19/migon.html.

20. Migoń K., O współczesnej sytuacji badawczej w naukach o ksiqż̇ce, bibliotece i informacji, „Przegląd Biblioteczny” R. 76: 2008, z. 1, s. 14-21. 
21. Migoń K., Teoria i metodologia nauki o książce, „Przegląd Biblioteczny” R. 51: 1983, z. 2/3, s. 177-184.

22. Nowak A., Nauka o ksiq̨żce w ujęciu Adama Łysakowskiego, „FIDES. Biuletyn Bibliotek Kościelnych" 2007, nr 1/2, s. 168-173.

23. Pomorski J., $W$ kierunku teoretycznej integracji badań bibliologicznych, „Studia o Książce” t. 15: 1985, s. 157-174.

24. Sordylowa B., Wzajemne relacje między dyscyplinami: informacja naukowa, bibliologia i bibliotekoznawstwo, „Przegląd Biblioteczny” R. 57: 1998, z. 4, s. 309-315.

25. Tobera M., Bibliologia wobec polskiego rynku ksiq̨żki w latach 1944-2007, „Przegląd Biblioteczny” R. 76: 2008, z. 1, s. 39-66.

26. Trzynadlowski J., Edytorstwo i zagadnienia wydawnicze. Stan i perspektywy badawcze, „Studia o Książce” t. 12: 1982, s. 59-66.

\section{Publishing issues in the field of bibliology}

ABSTRACT: The subject of this article is the presence of publishing issues in theoretical studies in the field of bibliology. The main objective of this paper is to present different ways of perceiving problems of publishing issues by theorists of book science. The analysis and review of literature method was used to analyze Polish works on the theory and methodology of book science published between 1975 and 2010. The analysis of main directions of theoretical and methodological reflection in book science was carried out and the basic directions of research on publishing issues in bibliology were set. The analysis allowed to make conclusions about the place of publishing issues in the field of book science.

KEYWORDS: analysis and review of literature, directions of research in book science, directions of research on publishing issues in bibliology, theoretical and methodological reflection in book science 